\title{
ANALYSIS OF SMALLHOLDER FARMERS REPAYMENT OF BANK OF AGRICULTURE LOAN IN EZZA SOUTH LOCAL GOVERNMENT AREA OF EBONYI STATE, NIGERIA (2009-2018)
}

\author{
Mbam, B. N. ${ }^{1}$ \\ Nwibo, S. U. ${ }^{2}$ \\ Nwofoke, C. $^{3+}$ \\ Egwu, P. N. ${ }^{4}$ \\ Odoh N.E. ${ }^{5}$
}

\author{
${ }_{1,2,9,4,5}$ Department of Agricultural Economics, Management and Extension, \\ Faculty of Agriculture and Natural Resources Management, Ebonyi State \\ University, Abakaliki, Nigeria. \\ 'Email:bonymbam@gmail.com \\ ${ }^{2}$ Email: sunwibo92@yahoo.com \\ ${ }^{s}$ Email:nwofoke.christian@ebsu.edu.ng \\ Email:triciaegrou@gmail.com \\ ${ }^{5}$ Email:ngodoh74@gmail.com
}

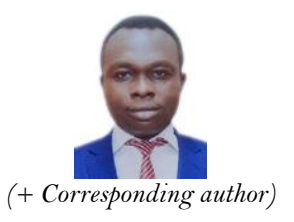

ABSTRACT
Article History

Received: 23 June 2021 Revised: 27 July 2021

Accepted: 19 August 2021

Published: 13 September 2021

\section{Keywords}

Loan repayment

Bank of agriculture

Smallholder farmers

Credit

Households

Ebonyi State
Smallholder farmer's repayment of Bank of Agriculture (BOA) loan in Ezza South Local Government Area of Ebonyi State was studied using 120 smallholder farmer beneficiaries selected using multistage sampling technique. Data were collected from primary source only using structured questionnaire and analyzed using both descriptive and inferential statistics. Results showed default of $32.3 \%$ as out of N333, 997,620.50 were disbursed to the farmers a total of $\mathrm{N} 226$, 080,887.00 were repaid. However, the socioeconomic characteristics of the loan beneficiaries contributed about $75 \%\left(\mathrm{R}^{2}=\right.$ 0.754) significant influence on repayment of Bank of Agriculture loan. Meanwhile, high interest rate, excessive bureaucracy, high rate of illiteracy, late approval of loan, lack of collateral, short payback period, and low farm output were identified as the major constraints to the repayment of $\mathrm{BOA}$ loan. It is recommended that as a measure to promote efficient and timely repayment of BOA loans by the farmers, management of BOA should address the institutional factors such as high interest rate, excessive bureaucracy and late approval of loan, high-value collateral and short payback period that were identified as the major constraints to BOA loan repayment.

Contribution/Originality: This study contributes in the existing literature on the repayment of Bank of Agriculture loan. It establishes that there is low repayment of BOA loan by the smallholder farmers in Ezza South Local Government Area of Ebonyi State, Nigeria.

\section{INTRODUCTION}

Agriculture is the major contributor to Nigeria's Gross Domestic Products (GDP) and smallholder farmers play a dominant role in this contribution. However, their productivity and growth are hindered by limited access to agricultural inputs especially credit thus, leading to the decline in the performance of the nation's agricultural sector. This has resulted in the country spending increasing high proportion of its foreign exchange earnings on importation of food for its teeming population culminating to slow rate of economic growth and development (Adofu, Orebiyi, \& Otitolaiye, 2012). Presently, the significant influence of agriculture in any economy across the globe cannot be overemphasized as it has remained the most dominant sector and indeed a major source of employment opportunity and other means of livelihood for citizens of many developing nations (Raham, Ahamed, \& Sarwer, 2011). Qureshi (2016) noted that any increase in agricultural production will result to industrialization 
since agriculture provides agro-allied products needed for industrial growth and development. Agriculture therefore serves as a catalyst for the growth of the entire economy. According to World Bank (2020) the global demand for food will increase by $70 \%$ by the year 2050 and at least $\$ 80$ billion annual investments will be needed to meet this demand, most of which needs to come from the private sector. One of the major inputs identified over the years as hindering the development of the Nigerian agriculture is lack of finance in form of credit to procure inputs needed for massive agricultural production (Central Bank of Nigeria (CBN), 2018).

The successive governments of Nigeria in recognition of the importance of credit in the overall development of agriculture intervened by initiating various policies and programmes aimed at solving the problem of credit among small holder farmers. Prominent among these policies and programmes is the establishment of the Nigerian Agricultural Co-operative Bank (NACB) in 1973now renamed Bank of Agriculture (BOA).Despite the establishment of this bank and the enactment of policies that led to the establishment of other allied financial institutions such as the Rural banking scheme, community banks (micro-finance banks) among others, the rural financial markets still remained under developed and agricultural development is still on the decline (Central Bank of Nigeria (CBN), 2005). The term agricultural credit can be defined as the temporary transfer of one's purchasing power to another person on request which allows the later the opportunity to command the transferred capital for agricultural purposes with intention of repaying back at a specified future date (Nwaru, 2004).Agricultural credit revolves round the act of making available fund to the farmers for the sole purpose of increasing their investment as well as output which will lead to improved standard of living (Shedrack, 2017). It is therefore an indispensable tool for achieving socioeconomic transformation of the rural communities which if well applied would stimulate capital formation and diversified agriculture, increase resource productivity and size of farm operations, promote innovations in farming, marketing efficiency and value addition while enhancing net farm incomes (Ohaka, 2013). It also enables the poor farmers to tap the financial resources and take advantage of the potentially profitable investment opportunities in their immediate environments (Mbam, 2017).

As the issue of lack of fund has become a great challenge to investment in the sector, there is need to tackle it through the process of credit lending, though lending has as well been identified as a very risky enterprise because repayment of loans cannot be assured on the parts of the borrowers (Shedrack, 2017). This was why Awoke and Okorji (2004) opined that in spite of the importance of credit in agricultural production, its acquisition and repayment are fraught with a number of problems such as loan diversion, excessive bureaucracy, delay in loan disbursement, high interest rate, high cost of loan procurement among other constraints. Other empirical studies on evaluations of the past loan scheme in the country attested to the fact that poor loan repayment is a major factor against the efficient delivery of credits to farmers in Nigeria. For instance, Anyanwu (2004) argued that conventional financial lending institutions in Nigeria often shy away from giving loans to famers due to high cost of loan administrating and high default rates among famers.

Also, Central Bank of Nigeria (CBN) (2005) report revealed that some farmers deliberately refuse to repay their loans as they erroneously believe that credit from the government is not supposed to be repaid while others do not repay their loans due to low income, devastating crop yield, ill health among other hazards. Furthermore, the above report showed that out of a total of 39 loans of over N15billion disbursed under Agricultural Credit Guarantee Scheme Fund (ACGSF) in Imo State between 1997 and 2004, only about N1.6 billion (10.9\%) was fully repaid, while the remaining were not fully repaid.

Though, there were several empirical reviews of the performance of banks and other financial institutions on credit administration cum delivery to farmers however, it seems that there is little or no in-depth study on repayment of BOA credit by small holder farmers in the study area. There is therefore a gap in information on the small holders' capacities to repay BOA loans in the study area, hence the need for this study.

In a bid to address the problems of this research, the study described the socioeconomic characteristics of BOA smallholder farmers loan beneficiaries; determined the amount of loan obtained and repaid by the smallholder 
farmers; determined the effect of socio-economic characteristics of the BOA smallholder loan beneficiaries on loan repayment; and analyzed the constraints to the repayment of BOA loans.

\section{METHODOLOGY}

The study area is Ezza-South Local Government Area (L.G.A) of Ebonyi State. Ezza South is one of the 17 L.G.As in Ebonyi State. It is located at the central senatorial zone of Ebonyi State with its headquarters at Onueke. It is bounded in the north, south, east and west by Abakaliki, Onicha, Ezza North and Ikwo L.G.As respectively. The population of the area is 195,565 people (National Population Census (NPC), 2006). The peoples in the area are predominantly farmers and the major crops produced in this area are yam, cassava, maize, rice, potato, cocoyam and vegetables.

They also engaged in livestock production such as goat, cattle, sheep and poultry. There is an existence of BOA branch office at Abakaliki capital city that service the entire L.G.A.s' in the state including the area under review. Both random and purposive sampling techniques were used to select the respondents used for this study. The first stage was random selection of four (4) communities out of the 10 communities existing in the L.G.A. The second stage was the random selection of two (2) villages from each the already selected four (5) communities, making a total of twenty-four (24) villages.

The third stage was the purposive selection of five (5) BOA farmers' loan beneficiaries, each from the twentyfour (24) villages already selected for the study, making a total of one hundred and twenty (120) respondents that constituted the sample size for the study. Primary data used for the study were obtained through field survey using structured questionnaire and interview schedule. Data collected were analyzed using descriptive and inferential statistics. Specifically, objectives 1 and 2 were analyzed using descriptive statistics, objective iii was realized with the aid of Ordinary Least Square (OLS) multiple regression model while iv was achieved using factor analysis.

\subsection{Model Specification}

2.1.1. Multiple Regression Model

The model showing the effect of socio-economic characteristics of the BOA smallholder loan beneficiaries on loan repayment is implicitly and explicitly shown in equation 1 and 2 respectively:

$$
\mathrm{Y}=\mathrm{F}\left(\mathrm{X}_{1}, \mathrm{X}_{2}, \mathrm{X}_{3} \mathrm{X}_{4}, \mathrm{X}_{5}, \mathrm{X}_{6} \mathrm{X}_{7}, \mathrm{X}_{8}\right)
$$

The explicit form of the model is represented thus;

$$
\mathrm{Y}=\mathrm{P}_{0}+\mathrm{P}_{1} \mathrm{X}_{1}+\mathrm{P}_{2} \mathrm{X}_{2}+\mathrm{P}_{3} \mathrm{X}_{3} \mathrm{P}_{4} \mathrm{X}_{4}+\mathrm{P}_{5} \mathrm{X}_{5}+\mathrm{P}_{6} \mathrm{X}_{6}+\mathrm{P}_{7} \mathrm{X}_{7}+\mathrm{P}_{8} \mathrm{X}_{8}+\mathrm{ut}
$$

Where;

$\mathrm{Y}=\mathrm{BOA}$ Loan repayment (Amount repaid from the loan).

$\mathrm{X}_{1}=$ Gender $($ male $=1$, female $=2)$.

$\mathrm{X}_{2}=$ Age (years).

$\mathrm{X}_{3}=$ Marital status (married $=1$, single $=2$, widow $=3$ ).

$\mathrm{X}_{4}=$ Household size (number of persons feeding from the same pot).

$\mathrm{X}_{5}=$ Farm size (hectare).

$\mathrm{X}_{7}=$ Educational qualification (number of years spent in school).

$\mathrm{X}_{6}=$ Annual farm income (naira).

$\mathrm{X}_{8}=$ Farming experience (years).

$\mathrm{P}_{1}-\mathrm{P}_{8}=$ estimated parameters.

$\mathrm{P}_{\mathrm{o}}=$ Constant. 


\section{RESULTS AND DISCUSSION}

\subsection{The Socio-Economic Characteristics of BOA Smallholder Farmer loan Beneficiaries}

The result of the analysis on gender as presented on Table 1 showed that majority (75\%) of the BOA farmer loan beneficiaries were male while only $25 \%$ were female. The reason for this could be due to some credit policies of most formal credit institutions that favour the male counterpart than the female such as provision of collateral, land ownership, paying of counterpart fund and other loan conditionality. Thus making women's ability in accessing credit to be solely dependent on the quality of relationship with the husband. However, this is not in agreement with the report of Adinya (2013) which reported that females were the main stream of traditional agriculture as women prepare, clear the land and engage in other aspects of farming activities. It was also observed that majority $(58.3 \%)$ of the beneficiaries' falls within the age range of $41-50$ years with a mean age of 43 years. This means that the farmers were still within the active and productive age that can undergo strenuous task associated with farm work to be able to repay bank loans. This is in line with the assertion of Ibrahim and Bauer (2013) who deduced that age has positive correlation with acceptance of innovations and risk taking which is critical to credit borrowing and eventual repayment of loans acquired for agricultural production. Furthermore, result of the analysis on marital status showed that majority (71.7\%) of the farmer loan beneficiaries was married. This could be because married people with the combined efforts of their spouses can manage their farm more efficiently in order to maximise profit and in turn be able to repay the acquired loans. Also, a mean household size of 6 persons implied that there could be availability of cheap labour which could reduce the overall cost of production thereby leading to increase in the individual farmer's capacity to repay loans. The result of the analysis which showed that majority $(66.7 \%)$ of the respondents cultivated between 1.1- 2.5 hectares of land means that the farmer loan beneficiaries had small farm sizes. This could inhibit the repayment capacities of the beneficiaries thus, synchronizing with the findings of Yusuf (2014) which reported that majority of the farmers in Nigeria are smallholders who engage in subsistence agriculture which could be just enough to meet their domestic needs.

The result equally showed that majority $(65 \%)$ of the beneficiaries attained a minimum of secondary school education while the least $(1.7 \%)$ had no formal education. This is not surprising as education enables farmers to excel in their farming endeavour especially in the area of credit assessment. This is contrary to the general opinion that most farmers in Nigeria are illiterate or semi-illiterate as was revealed by the studies conducted by Awoke and Okorji (2004). Again, majority (56.7\%) of the respondents had annual income of between N60, 001 -N90, O00 with an average annual income of N78, 425.4. Since the distribution classifies the majority of the respondents as belonging to the low income earners, it therefore implies that it could affect the rate of loan repayments of the beneficiaries. This is because such farmers will be battling just to cater for the welfare of their households and this could jeopardize their interest in repaying their loans as at when due. The study equally deduced that majority $(75.8 \%)$ of the respondents have mean farming experience of 10 years. This implies that years of experience in farming are positively related to access and eventual acquisition and utilization of loan from the bank. This is because ceteris paribus, the more years an individual spent in farming, the higher would be his capacity to acquire and utilize credit facilities given the higher accumulated resources at the individual's disposal to acquire the collateral needed for loan procurement.

\subsection{Amount of Loan Obtained and Repaid by BOA Loan Beneficiaries}

The amount of loan acquired from BOA for agricultural production and amount repaid by the respondents as at the stipulated payback periods for a decade (2006-2015) was analysed and result is as presented in Table 2.

Result of the analysis showed that a total of N333, 997,620.50was disbursed within 2006 - 2015 whereas only a total of N226, 080,887.00 was repaid during the year under review, leaving an outstanding balance of N107, 916,733.50. Also, the mean (N33, 399,762.05) amount of loan obtained was higher than the mean (N22, 608,088.70) amount repaid. The discrepancy observed between the amount of loan obtained and repaid implies that there was 
much loan default in the area. This result is in agreement with Adeyonu (2015) who reported that there was high rate of loan default among smallholder cooperative farmers in Remo division, Ogun State, Nigeria. Also, the result of the analysis was in tandem with Abula, Otitolaiye, Ibitoye, and Orebiyi (2013) that rural farmers who benefitted from Microfinance Banks loan in Kogi State, Nigeria were found to have defaulted with about $15-30 \%$ of the initial loan borrowed. Furthermore, this work fell in compromise with Anigbogu, Onugu, Onyeugbo, and Okoli (2014) who reported that most of the cooperative farmers in Awka North L.G.A of Anambra state, Nigeria did not completely repay the loan they procured from the bank.

Table-1. Distribution of respondents according to their Socio-economic characteristics.

\begin{tabular}{|c|c|c|c|c|}
\hline Characteristics & Description & Frequency $(\mathrm{N}=120)$ & Percentage & Mean \\
\hline \multicolumn{5}{|l|}{ Gender } \\
\hline & Male & 90 & 75.0 & \\
\hline & Female & 30 & 25.0 & \\
\hline \multirow[t]{5}{*}{ Age } & $21-30$ & 15 & 12.5 & \\
\hline & $31-40$ & 15 & 12.5 & \\
\hline & $41-50$ & 70 & 58.3 & \\
\hline & $51-60$ & 30 & 25.0 & 43 \\
\hline & $\geq 60$ & 5 & 4.3 .0 & \\
\hline \multicolumn{5}{|l|}{ Marital status } \\
\hline & Married & 86 & 71.7 & \\
\hline & Single & 30 & 25.0 & \\
\hline & Widowed & 4 & 3.3 & \\
\hline \multicolumn{5}{|l|}{ Household size } \\
\hline & $\leq 3$ & - & & \\
\hline & $3-5$ & 42 & 35.0 & \\
\hline & $6-8$ & 58 & 48.3 & \\
\hline & $\geq 8$ & 20 & 16.7 & \\
\hline \multicolumn{5}{|l|}{ Farm size } \\
\hline & $\leq 0.5$ & 10 & 8.3 & \\
\hline & $0.5-1.0$ & 28 & 20.8 & \\
\hline & $1.1-2.5$ & 80 & 66.7 & \\
\hline & $\geq 2.5$ & 5 & 4.2 & \\
\hline \multicolumn{5}{|l|}{ Educational level } \\
\hline & No formal & 2 & 1.7 & \\
\hline & Primary school & 19 & 15.8 & \\
\hline & Secondary school & 78 & 65.0 & \\
\hline & Tertiary & 21 & 17.5 & \\
\hline \multicolumn{5}{|c|}{ Annual farm income $(\mathrm{N})$} \\
\hline & $<10,000$ & - & & \\
\hline & $10,001-30,000$ & -18 & 15.0 & \\
\hline & $30,001-60,000$ & 30 & 25.0 & \\
\hline & $60,001-90,000$ & 68 & 56.7 & $78,425.4$ \\
\hline & $90,001-120,000$ & 3 & 2.5 & \\
\hline & $\geq 121,000$ & 1 & 0.8 & \\
\hline \multicolumn{5}{|c|}{ Farming experience (years) } \\
\hline & $1-5$ & 2 & 1.7 & \\
\hline & $6-10$ & 18 & 15.0 & 10.4 \\
\hline & $11-15$ & 91 & 75.8 & \\
\hline & $16-20$ & 9 & 7.5 & \\
\hline
\end{tabular}

\subsection{Effects of Socio-Economic Characteristics of Bank of Agriculture Loan Beneficiaries on Loan Repayment}

Multiple regression analysis was adopted to analyze the effects of socio-economic characteristics of BOA loan beneficiaries on loan repayment. Some of the socio-economic attributes that affect the farmer beneficiaries' loan repayments were age, marital status, household size, farm size, level of education, annual farm income and farming experience. The result of the analysis showed that the socio-economic characteristics of the loan beneficiaries have 
significant influence on their loan repayments. This was indicated by the presence of a high value of $\mathrm{R}^{2}(0.754)$ as presented in Table 3.

Table-2. Amount of loan obtained and repaid by BOA loan beneficiaries in the area (in naira).

\begin{tabular}{|c|c|c|c|c|}
\hline Years & Amount disbursed & Amount repaid & Outstanding balance & Rate of repayment \\
\hline 2010 & $15,456,575.00$ & $9,748,250.00$ & $5,708,325.00$ & 63,2 \\
\hline 2011 & $21,322,860.50$ & $13,485,255.05$ & $7,837,605.45$ & 63.2 \\
\hline 2012 & $8,895,655.00$ & $5,058,674.00$ & $3,836,981.00$ & 56.9 \\
\hline 2013 & $25,845,840.00$ & $18,811,205.00$ & $7,034,635.00$ & 72.8 \\
\hline 2014 & $38,558,440.00$ & $24,898,490.00$ & $13,659,950.00$ & 64.6 \\
\hline 2015 & $41,960,220.00$ & $29,940,100.00$ & $12,020,120.00$ & 71.4 \\
\hline 2016 & $30,125,265.00$ & $19,995,714.19$ & $10,129,550.81$ & 66.4 \\
\hline 2017 & $54,650,860.00$ & $38,675,652.15$ & $15,975,207.85$ & 70.8 \\
\hline 2018 & $61,631,255.00$ & $46,787,096.12$ & $14,844,158.88$ & 75.9 \\
\hline 2019 & $35,550,650.00$ & $18,680,450.50$ & $16,870,199.50$ & 52.6 \\
\hline Total Mean & $\begin{array}{c}333,399,620.50 \\
33,399,762.05\end{array}$ & $\begin{array}{l}226,080,887.00 \\
22,608,088.70\end{array}$ & $107,916,733.50$ & 67.8 \\
\hline
\end{tabular}

Specifically, the result of the regression analysis revealed that age $\left(\mathrm{x}_{2}\right)$ was positive and statistically significant at $1 \%(\mathrm{P}=0.01)$ level. This implies that age of the beneficiaries has influence on the decision to acquire and repay loans in order to redeem the individual farmer's image within the society as well as be able to have access to more loan facilities in due course from the bank. This conformed to the a priori expectation that as one advances in age, the zeal and capacity to borrow and repay loan facilities increases. However, this phenomenon dwindles as one approaches non productive old age. This discovery is in logger head with Girabi and Mwakaje (2013) who opined that as an individual advances in age, the responsibilities such as raising of children, payment of school fees and health services increases which could reduce their repayment capacity. Similarly, Bime (2008) found that age has an inverse relationship with investment in honey agribusiness because as a farmer advances in age, his desire to invest in the business decreases thus, leading to low repayment of loans. However, this result is in consonance with the views Ajagbe (2012) which inferred that the demand and loan repayment was strongly influenced by age and other dwelling characteristics such as state of health, income status and the prevailing political situation of the country.

Also, the coefficient of marital status $\left(\mathrm{x}_{3}\right)$ bore positive coefficient and was statistically significant at $5 \%$ $(\mathrm{P}=0.01)$ level. This implies that marital status has great influence on the BOA loan repayment capacities as beneficiaries who are married are deemed to be more responsible in the society than other categories of people and as such, they are more likely to repay loans more promptly in order to maintain their social status. Also, married people are likely to possess more hands who can work in the farm as cheap labour such as wives and children. This is in conformity with the findings of Ayanda and Ogunsekan (2012) which reported that wives and children can serve as a source of labour which may lead to increase in farm size and overall level of farm productivity that led to higher repayment. This is also consistent with the findings of Yaqub (2012) which reported that majority (68.4\%) of the micro-credit beneficiaries in Alimosho L.G.A of Lagos State, Nigeria were married thus, leading to availability of cheap farm labour that resulted to more farm output in the area.

The coefficient of household size $\left(\mathrm{x}_{4}\right)$ of the beneficiaries was negative but statistically significant at $10 \%(\mathrm{P}$ $=0.10$ ) level. This means that increase in household size, increases family responsibilities of the household heads and in turn lead to increase in the diversion of the loan that was due for repayment thereby leading to decrease in loan repayment hence a priori expectation was met. This is partially in tandem with the result of the findings of Nwibo and Mbam (2013) which argued that household size of the respondents was negative and statistically significant at $1 \%(\mathrm{P}=001)$ level. Hence, farmers with large household size spend more money for their family upkeep and as such cannot save to be able to repay loans procured at the stipulated repayment periods. Also, this result is justified as the earlier findings of Otunaiya, Ologbon, and Akerele (2014) inferred that farmers with large household size are 
not more likely to seek for loan but when they do, they are more likely to have lower capacity to repay their loans due to family encumbrances and responsibilities.

The farm size $\left(\mathrm{x}_{5}\right)$ bore positive coefficient and was statistically significant at $5 \%(\mathrm{P}=0.05)$ level. This implies that an increase in farm size will invariably mean an increase in the repayment of the loan borrowed from the bank by a farmer thus; the a priori expectation was met as the higher the size of farm, the more the profit margin expected of such individual farm which invariably can lead to increase in the repayment capacity of such an individual farmer. This result is in conformity with the findings of Wongnaa and Awunyo-Vitor (2013) that the size of a yam farm in Sene District of Ghana had a positive relationship with loan repayment abilities of the farmers as most of the yam farmer loan beneficiaries with high farm size repaid their loans more promptly than those that have small farms. However, this finding contradicts (Mgbebu \& Achike, 2017) who found that farm sizes of rice farmers in Ebonyi State have no significant influence on their loan repayment capacities.

The educational level $\left(\mathrm{x}_{6}\right)$ of the BOA loan beneficiaries has a direct relationship with their repayment capacities as was shown by its coefficient being positive and statistically significant at $5 \%(\mathrm{P}=0.5)$ level. This implies that the higher the level of educational attainment of a loan beneficiary, the higher will be the individual's capacity to repay the loan acquired. This is because such an individual farmer might employ his intellectual property acquired from school in the management of his farming order to enhance his output and productivity thereby leading to increase in his repayment capacity. This work is consistent with Awunyo-Vitor (2012) who reported that in Brong Ahafo Region of Ghana, increase in educational level has direct relationship with the farmers' understanding of the need for farm loans and its eventual repayment. Also, Ojiako, Idowu, and Ogbukwa (2014) reported that loan repayment behaviour of smallholder cooperative farmers in Yewa North Local Government Area of Ogun State Nigeria, increased as their educational level increased. Also, consistent with this finding is Ayanda and Ogunsekan (2012) who purported that access to education provides a favourable atmosphere for awareness of innovations which hitherto enhanced the farmers' outputs and productivities.

The annual farm income $\left(\mathrm{x}_{7}\right)$ bore positive coefficient and statistically significant at $1 \%(\mathrm{P}=0.01)$ level. This implies that increase in the annual farm income of an individual farmer will lead to increase in his repayment capacity. Hence, the a priori expectation was met since ceteris paribus, increase in the farmers' annual income will lead to increase in their farm investment which hitherto will yield more returns that will enable them to repay the acquired loans. Thus, the reliability of this result is confirmed as the findings of Saleem, Jan, Khattak, and Quraishi (2014) showed that due to marginal increase in farmers' income in 2013, there were drastic increase in their farm outputs and massive repayments of loans procured from banks in Kebbi State of Nigeria. Again, Tundui and Tundui (2013) posited that among the factors that positively influenced the women farmers' loan repayment capacity in Tanzania was annual income as this enabled the farmers to adopt appropriate innovations needed for improved farming in the area.

The coefficient of farming experience $\left(\mathrm{x}_{8}\right)$ was positive and statistically significant at $5 \%(\mathrm{P}=0.05)$ level. This implies that as a loan beneficiary's experience in farming increases, his capacity to repay loan increases. This is because; the individual might have acquired better experiences in handling production resources in farming which could lead to higher level of output and productivity that can translate to increase in income vis a vis increase in his repayment capacity, ceteris paribus. Therefore, the a priori expectation was met as increase in farming experience, increases the technical efficiency of production thereby leading to higher income which can in turn leads to loan repayment. This was in tandem with Mgbebu and Achike (2017) who reported that years of experience bore a positive co-efficient of magnitude 0.562 while its t-value was 1.986 which was significant at $10 \%$ probability level implying that there was a high probability of more experienced farmers to repay loan obtained from lending agencies in the area. It as well corroborates (Akanni, 2007) who reported that more number of years of experience in poultry keeping had a positive and significant relationship with the ability of loan beneficiaries to manage poultry business, hence higher outputs and productivities leading to increase in their loan repayment capacities. 
Table-3. Summary of the regression result.

\begin{tabular}{l|c|c|c|c}
\hline Variables & Coefficients & Std. error & t & Sig. \\
\hline Constant & 1.439 & 0.426 & -1.514 & .001 \\
\hline Gender & -0.124 & 0.082 & -1.514 & NS \\
\hline Age & 0.015 & 0.081 & 0.182 & .001 \\
\hline Marital status & 0.041 & 0.084 & 0.454 & .001 \\
\hline Educational level & 0.131 & 0.085 & 1.529 & .005 \\
\hline Household size & -0.063 & 0.080 & 0.789 & .010 \\
\hline Farm size & 0.193 & 0.082 & 2.340 & .005 \\
\hline Annual farm income & 0.157 & 0.140 & 1.116 & .001 \\
\hline Farming experience & 0.241 & 0.043 & 0.815 & .005 \\
\hline $\mathrm{R}^{2}$ adjusted & 0.754 & & & \\
\hline Durbin Watson & 1.341 & & & \\
\hline Source: Computed regression output, 2019. & & &
\end{tabular}

\subsection{Constraint to BOA Loans Repayment by the Farmer Beneficiaries in the Area}

Loan repayment is a critical factor in loan administration as it has impact on further access and sustainability of funds needed for enhanced farmers' productivities and outputs. It is due to importance of this variable that the factors constraining its workability was analysed in this section (Table 4). This was analysed with the aid of Varimax Rotated Principal Component Analysis using the rule of thumb of 0.40 as a bench mark in naming the variables as was adopted (Nwibo. \& Alimba, 2013). The factors were grouped into three components viz. Institutional, education/information and economic problems. The result of the analysis revealed the major institutional factors constraining the repayment of BOA loans to include high interest rate, excessive bureaucracy and late approval of loan. Also, the education/information factors constraining the beneficiaries from the repayment of the bank's loan were high rate of illiteracy of the farmers, lack of collateral and short payback period while low farm output was the only major factor isolated as economic factor that constrained the farmer beneficiaries from repaying the BOA loan. This corroborates (Onoja \& Emodi, 2012) who found that low output, bureaucracy, low income, low market price, family responsibilities and rise in production cost as the major constraints to loan repayment. Again, Ezihe, Akpa, and Ayoola (2016) posited that the major constraints to loan repayment among farmers in Benue State were high interest rate and quick repayment period. Similarly, Kuye and Edem (2019) submitted that the salient constraints to repayment of loan among cassava farmers in Akpabuyo Local Government Area of Cross River State, Nigeria were high interest rate and short period of repayment among others. Furthermore, Ogonna, Nonyelum, and Nwankwo (2018) disclosed that the major constraints to repayment of credit by rural farmers in Anambra State were; illiteracy, high interest rate, untimely loan repayment period and late loan approval.

Table-4. Varimax rotated component factors on constraints to loan repayment among BOA loan beneficiaries in the area.

\begin{tabular}{l|l|c|c|c}
\hline $\mathbf{S} / \mathbf{N}$ & Variable & $\begin{array}{c}\text { Factor 1 } \\
\text { institutional } \\
\text { Problem }\end{array}$ & $\begin{array}{c}\text { Factor 2 } \\
\text { Education/Information } \\
\text { Problem }\end{array}$ & $\begin{array}{c}\text { Factor 3 Economic } \\
\text { Problem }\end{array}$ \\
\hline $\mathrm{V}_{1}$ & High interest rate & 0.589 & -0.097 & -0.079 \\
\hline $\mathrm{V}_{2}$ & Illiteracy & -0.158 & 0.638 & -0.334 \\
\hline $\mathrm{V}_{3}$ & Excessive bureaucracy & 0.488 & -0.374 & -0.348 \\
\hline $\mathrm{V}_{4}$ & Late approval of loan & 0.677 & -0.079 & 0.288 \\
\hline $\mathrm{V}_{5}$ & Low farm output & -0.145 & 0.015 & 0.858 \\
\hline $\mathrm{V}_{6}$ & Lack of collateral & -0.659 & 0.444 & 0.063 \\
\hline $\mathrm{V}_{7}$ & Short payback period & 0.008 & 0.486 & 0.028 \\
\hline $\mathrm{V}_{8}$ & Untimely loan disbursement & -0.046 & -0.758 & 0.138 \\
\hline $\mathrm{V}_{9}$ & Far distance to the bank & -0.504 & -0.027 & -0.093 \\
\hline \multicolumn{2}{l}{ source: Field survey, 2019. }
\end{tabular}




\section{CONCLUSION AND RECOMMENDATIONS}

The study showed that there was low rate of loan repayment among the farmer beneficiaries of BOA as a mean amount of loans obtained was significantly higher than the mean amount repaid within the period under study. Based on the findings, it was recommended that in designing policies for the approval of loans for the smallholder farmers, the management of the bank should lay more emphasis on those variables that significantly affects loan repayment capability of the farmers such as high interest rate, collateral, time of disbursement, bureaucracy. These if reconditioned will enable the farmers to have easy access to the loan facilities and then be able to repay their loans at a stipulated time. Also, farmers on their part should be trained on the use and management of fund in order to optimally produce and be able repay BOA loans in due time.

Funding: This study received no specific financial support.

Competing Interests: The authors declare that they have no competing interests.

Acknowledgement: All authors contributed equally to the conception and design of the study.

\section{REFERENCES}

Abula, M., Otitolaiye, J., Ibitoye, S., \& Orebiyi, J. (2013). Repayment performance of rural farmer's loan beneficiaries of microfinance banks in Kogi State, Nigeria (2005-2010). International Journal of Farming and Allied Sciences, 2(5), 104110.

Adeyonu, A. G. (2015). Determinants of loan repayment among Smallholder cooperative farmers in Remo Division, Ogun State, Nigeria. Journal of Agricultural Science, 8(1), 92 - 99.

Adinya, I. B. (2013). Factors influencing labour utilization in small scale cassava production: A case study of Uyo agricultural zone of Akwa Ibom State, Nigeria. Unpublished M. Sc. Dissertation, Department of Agricultural Economics/Extension, University of Uyo, Nigeria.

Adofu, I., Orebiyi, J. S., \& Otitolaiye, J. O. (2012). Repayment performance anddeterminants of food crop farmers loan beneficiaries of Nigeria agricultural cooperative and rural development bank (NACRDB) in Kogi State, Nigeria (2008 2010). Journal of Development and Agricultural Economics, 4(5), 20 - 40.

Ajagbe, F. (2012). Features of small scale entrepreneur and access to credit in Nigeria: A microanalysis. America Journal of Social and Management Sciences, 3(1), 39 -44. Available at: https://doi.org/10.5251/ajsms.2012.3.1.39.44.

Akanni, K. (2007). Effect of micro-finance on small scale poultry business in South Western Nigeria. Emirates Journal of Food and Agriculture, 19(2), 38-47. Available at: https://doi.org/10.9755/ejfa.v12i1.5174.

Anigbogu, T. U., Onugu, C. U., Onyeugbo, B. N., \& Okoli, M. I. (2014). Determinants of loan repayment among cooperative farmers in Awka North LGA of Anambra State, Nigeria. European Scientific Journal, 10(22), 56-72.

Anyanwu, C. M. (2004). Micro-finance institutions in Nigeria: Policy, practice, and potentials. Paper presented at the G24 Workshop on Constraints to Growth in Sub-Saharan Africa, Pretoria, South Africa. November 29-30, 2004.

Awoke, M. U., \& Okorji, E. C. (2004). The determination and analysis of constraints in resource use efficiency in multiple cropping systems by small-holder farmers in Ebonyi State, Nigeria. Africa Development, 29(3), 58- 69. Available at: https://doi.org/10.4314/ad.v29i3.22199.

Awunyo-Vitor, D. (2012). Determinants of loan repayment default among farmers in Ghana. Journal of Development and Agricultural Economics, 4(13), 339-345.

Ayanda, I., \& Ogunsekan, O. (2012). Farmers' perception of repayment of loans obtained from Bank of Agriculture, Ogun state, Nigeria. Journal of Agricultural Sciences, 3(1), 21-27. Available at: https://doi.org/10.1080/09766898.2012.11884681.

Bime, M. J. (2008). Savings mobilization and rural credit markets performance in the North West Province, Cameroon. Ph.D Thesis Submitted to the Department of Agricultural Economics, Michael Okpara University of Agriculture, Abia State Nigeria.

Central Bank of Nigeria (CBN). (2005). The real sector C.B.N. annual report and statement of account for the year ended 31 st December, 2005. Abuja, Nigeria: C.B.N Publication. 
Central Bank of Nigeria (CBN). (2018). Monetary, credit, foreign. Trade and exchange policy. Monetary Policy Circular, No. 28.

Ezihe, J., Akpa, J., \& Ayoola, J. (2016). Accessibility and repayment of agricultural loan among farmers in Benue State, Nigeria. IOSR Journal of Agriculture and Veterinary Science, 9(8), 39-46. Available at: https://doi.org/10.9790/2380-0908023946.

Girabi, F., \& Mwakaje, A. E. G. (2013). Impact of microfinance on smallholder farm productivity in Tanzania: The case of Iramba District. Asian Economic and Financial Review, 3(2), 227 - 242.

Ibrahim, A. H., \& Bauer, S. (2013). Access to micro credit and its impact on farm profit among rural farmers in dryland of Sudan. Global Advanced Research Journal of Agricultural Science, 2(3), 88-102.

Kuye, O., \& Edem, T. (2019). Determinants of loan repayment among small-scale cassava farmers in Akpabuyo local government area of Cross River State, Nigeria. Asian Journal of Agricultural Extension, Economics \& Sociology, 1-11. Available at: https://doi.org/10.9734/ajaees/2019/v35i330221.

Mbam, B. N. (2017). Analysis of formal micro-credit utilization for rice technologies adoption in South East Nigeria. International Journal of Science and Research (IJSR), 6(4), 1603 - 1607.

Mgbebu, E. S., \& Achike, I. A. (2017). Analysis of loan acquisition and repayment among small scale rice farmers in Ebonyi State, Nigeria: Implication for effective credit delivery. IOSR Journal of Economics and Finance, 8, 20-26. Available at: https://doi.org/10.9790/5933-0803012026.

National Population Census (NPC). (2006). Official population figure of Ezza South local government area of Ebonyi State, Nigeria. Abuja Nigeria: National Population Headquarters.

Nwaru, J. C. (2004). Rural credit market and resource use in arable crop production in Imo State of Nigeria. PhD Dissertation, Michael Okpara University of Agriculture, Umudike, Nigeria.

Nwibo, S., \& Mbam, B. (2013). Determinants of savings and investment capacities of farming households in Udi local government area of Enugu State, Nigeria. Research Journal of Finance and Accounting, 4(15), 59-68.

Nwibo., S., \& Alimba, J. (2013). Determinants of investment decisions among agribusiness investors in South-East, Nigeria. Journal of Business and Management, 8(6), 60-67. Available at: https://doi.org/10.9790/487x-0866067.

Ogonna, O. O., Nonyelum, M. A., \& Nwankwo, T. N. (2018). Utilization of commercial agricultural credit scheme loans and repayment performance by beneficiary farmers in Anambra State, Nigeria. IOSR Journal of Agricultural Veterinary Service, $11(7), 65-73$.

Ohaka, C. (2013). Improving agricultural productivity through integrated service: Provision with public-private partnerships (pp. 15-25). Working Paper No. 66. Colombia, Sri Lanka: International Water Management Institute, Colombia Sri Lanka.

Ojiako, I. A., Idowu, A., \& Ogbukwa, C. (2014). Determinants of loan repayment behaviour of smallholder cooperative farmers in Yewa North local government area of Ogun State, Nigeria: An application of Tobit model. Journal of Economics and Sustainable Development, 5(16), 144-153.

Onoja, A. O., \& Emodi, A. I. (2012). Analysis of gender and poverty effects on loan defaults rate among arable crop farmers in Rivers State, Nigeria. Journal of Agricultural Extension and Rural Development, 4(18), 478-485.

Otunaiya, A. O., Ologbon, O. A. C., \& Akerele, E. O. (2014). Analysis of agricultural loan use decision among poultry farmers in Oyo State, Nigeria. International Journal of Poultry Science, 13(2), 108-113. Available at: https://doi.org/10.3923/ijps.2014.108.113.

Qureshi, L. (2016). Microcredit and agricultural productivity in Ogun State, Nigeria. World Journal of Agricultural Sciences, 6(3), 290-296.

Raham, M. W., Ahamed, M. R., \& Sarwer, R. H. (2011). An investment of ground water irrigation and command and area management issues in Bangladesh. Journal of Knowledge Globalization, 4(1), 93-114.

Saleem, A., Jan, F. A., Khattak, R. M., \& Quraishi, M. I. (2014). Impact of farm and farmers characteristics on repayment of agriculture credit. Abasyn Journal of Social Sciences, 4(1), 23-35.

Shedrack, U. (2017). Analysis of loan delinquency among small-scale farmers in southwestern Nigeria: Application of Logit and loan performance indices. East Africa Agricultural and Forestry Journal, 29(3), 275-294. 
Tundui, C. S., \& Tundui, H. (2013). Microcredit, micro enterprising and repayment Myth: The case of micro and small women business entrepreneurs in Tanzania. American Journal of Business and Management, 2(1), 20-30. Available at: https://doi.org/10.11634/216796061302240.

Wongnaa, C., \& Awunyo-Vitor, D. (2013). Factors affecting loan repayment performance among yam farmers in the Sene District, Ghana. Agris On-Line Papers in Economics and Informatics, 5(2), 111-122.

World Bank. (2020). Understanding poverty. A brief on agriculture finance $\mathcal{E}$ agriculture insurance: World Bank.

Yaqub, J. O. (2012). Micro-credit and welfare of micro entrepreneurs in Nigeria: A case study of Alimosho local government area of Lagos state. Journal of Business and Organizational Development, 4, 12-21.

Yusuf, S. A. (2014). Role of agriculture in economic growth and development: Nigeria perspective. Munich Personal RePEc Archive, University of Lagos, Akoka, Lagos, Nigeria. Paper No. 55536.

Views and opinions expressed in this article are the views and opinions of the author(s), International Journal of Sustainable Agricultural Research shall not be responsible or answerable for any loss, damage or liability etc. caused in relation to/arising out of the use of the content. 